\title{
The Pathway to Cancer Cachexia: MicroRNA-Regulated Networks in Muscle Wasting Based on Integrative Meta-Analysis
}

\author{
Paula Paccielli Freire ${ }^{1}{ }^{\mathbb{D}}$, Geysson Javier Fernandez ${ }^{1}$, Sarah Santiloni Cury ${ }^{1}{ }^{\mathbb{D}}$, \\ Diogo de Moraes ${ }^{1}$, Jakeline Santos Oliveira ${ }^{1}$, Grasieli de Oliveira ${ }^{1}$, Maeli Dal-Pai-Silva ${ }^{1}$, \\ Patrícia Pintor dos Reis ${ }^{2,3}$ (D) and Robson Francisco Carvalho $1, *$ (D) \\ 1 Department of Morphology, Institute of Biosciences, São Paulo State University (UNESP), Botucatu, \\ São Paulo 18.618-619, Brazil; paula.freire@unesp.br (P.P.F.); jasonfergar@hotmail.com (G.J.F.); \\ sarahscury@gmail.com (S.S.C.); demoraesdiogo2017@gmail.com (D.d.M.); jakoliveira.jo@gmail.com (J.S.O.); \\ oliveira.grase@gmail.com (G.d.O.); maeli.dal-pai@unesp.br (M.-D.-P.-S.) \\ 2 Department of Surgery and Orthopedics, Faculty of Medicine, São Paulo State University (UNESP), \\ Botucatu, São Paulo 18.618-687, Brazil; patricia.reis@unesp.br \\ 3 Experimental Research Unity, Faculty of Medicine, São Paulo State University (UNESP), Botucatu, \\ São Paulo 18.618-687, Brazil \\ * Correspondence: robson.carvalho@unesp.br; Tel.: +55-14-3880-0473
}

Received: 12 March 2019; Accepted: 11 April 2019; Published: 22 April 2019

\begin{abstract}
Cancer cachexia is a multifactorial syndrome that leads to significant weight loss. Cachexia affects $50 \%-80 \%$ of cancer patients, depending on the tumor type, and is associated with $20 \%-40 \%$ of cancer patient deaths. Besides the efforts to identify molecular mechanisms of skeletal muscle atrophy-a key feature in cancer cachexia-no effective therapy for the syndrome is currently available. MicroRNAs are regulators of gene expression, with therapeutic potential in several muscle wasting disorders. We performed a meta-analysis of previously published gene expression data to reveal new potential microRNA-mRNA networks associated with muscle atrophy in cancer cachexia. We retrieved 52 differentially expressed genes in nine studies of muscle tissue from patients and rodent models of cancer cachexia. Next, we predicted microRNAs targeting these differentially expressed genes. We also include global microRNA expression data surveyed in atrophying skeletal muscles from previous studies as background information. We identified deregulated genes involved in the regulation of apoptosis, muscle hypertrophy, catabolism, and acute phase response. We further predicted new microRNA-mRNA interactions, such as miR-27a/Foxo1, miR-27a/Mef2c, miR-27b/Cxcl12, $\mathrm{miR}-27 \mathrm{~b} / \mathrm{Mef2c}$, miR-140/Cxcl12, miR-199a/Cav1, and miR-199a/Junb, which may contribute to muscle wasting in cancer cachexia. Finally, we found drugs targeting MSTN, CXCL12, and CAMK2B, which may be considered for the development of novel therapeutic strategies for cancer cachexia. Our study has broadened the knowledge of microRNA-regulated networks that are likely associated with muscle atrophy in cancer cachexia, pointing to their involvement as potential targets for novel therapeutic strategies.
\end{abstract}

Keywords: cancer cachexia; microRNAs; transcriptome; protein-protein interaction networks

\section{Introduction}

Cachexia is a syndrome associated with pathological conditions, including sepsis, chronic obstructive pulmonary disease, heart failure, and cancer [1,2]. Notably, cachexia is the leading cause of death for $20 \%-40 \%$ of cancer patients [3], and affects around $60 \%$ of patients when all cancer types are 
considered [4]. Cachexia is more prevalent in gastric or pancreatic cancer, as up to $80 \%$ of patients may develop the syndrome $[5,6]$.

Cachexia occurs in all cancer stages, and is associated with poor prognosis, decreased treatment tolerance, and a significant reduction in quality of life [7]. International consensus defines the diagnostic for cancer cachexia based on weight loss greater than $5 \%$ over six months, or weight loss greater than $2 \%$ in individuals with a body mass index lower than $20 \mathrm{~kg} / \mathrm{m}^{2}$ or with sarcopenia [7]. Other features associated with cancer cachexia are a reduction in food intake, an increase of systemic inflammation markers like C-reactive protein, and decreased response to chemotherapy [7]. These features may increase surgical risk in cachectic patients [7,8]. Thus, the conservation of lean body mass is critical for cancer patients' survival. Although there are some advances in therapeutic strategies for muscle wasting in cancer cachexia (reviewed in [4]), effective targets to treat the syndrome are still lacking.

Many studies have been conducted to identify the molecular mechanisms related to muscle wasting in cancer cachexia. These studies have already lead to important advances through the recognition of the association between cachexia and high levels of pro-inflammatory cytokines, such as interleukin (IL)-1 $\beta$, IL-6, IL-8, tumor necrosis factor alpha (TNF), and interferon gamma (IFN) [9-14]. These cytokines activate different molecular axes in skeletal muscle cells by the nuclear factor kappa-light-chain-enhancer of activated B cells (NF-kB), signal transducer and activator of transcription (STAT), MAP kinase family (MAPKs), and activator protein 1 (AP1) [15-18]. Signal transductions to NF-KB and STAT transcription factors have key roles, especially in altering three major effector biological systems: the ubiquitin-proteasome system, the IGF1-AKT-FOXO signaling pathway, and the autophagy-lysosome system [19-21]. Together, these systems contribute to an imbalance between protein synthesis and degradation that results in loss of muscle mass and function [19-21]. Given the complexity of these processes leading to muscle atrophy, the identification and characterization of new genes and signaling pathways based on global analysis will likely contribute to the understanding of the underlying molecular mechanisms of muscle wasting in cancer cachexia.

In fact, global gene expression studies of muscle wasting conditions, such as glucocorticoid treatment, immobilization, unloading, diabetes, sarcopenia, starvation, and denervation [22-27], have helped to shed light on the molecular mechanisms of muscle atrophy, including the identification of new potential biomarkers of cancer cachexia $[28,29]$. The identification of microRNAs has also broadened the knowledge about global gene expression regulation in conditions that induce skeletal muscle atrophy [30-33], including cancer cachexia [34,35]. However, there is a lack of integration of global microRNA and mRNA expression data from the same set of muscle samples in previous cancer cachexia studies $[28,29,34-41]$. Furthermore, to our knowledge, no study has integrated the most relevant microRNA and mRNA data available in the literature. Such integrative strategies are important for identifying the functional significance of key deregulated genes, microRNAs, and molecular pathways involved in muscle wasting in cachexia.

Moreover, the high diversity among human and animal models with cancer cachexia, the complexity of the syndrome, the difficulties in recruiting patients for studies, and the heterogeneity of cancer cells and muscle phenotypes leads to low translatability from experimental systems to clinical practice [42]. We performed a systematic integration of validated gene expression data derived from global mRNA and microRNA expression profiles in muscle wasting in cancer cachexia, to capture the most relevant microRNA-regulated networks across multiple human and rodent studies. Our analysis identified new molecular pathways potentially involved in skeletal muscle atrophy in cancer cachexia. These data have also proven useful for identifying new, potentially molecular-targeted treatment strategies for the syndrome. 


\section{Results}

\subsection{Study Selection and Characteristics}

The meta-analysis resulted in nine studies reporting skeletal muscle gene expression data in cancer cachexia $[28,29,36-41,43]$. The process to select the studies is summarized in Figure 1 . We present the description of publicly available cancer cachexia studies included in the meta-analysis in Table 1. These studies report muscle gene expression data from patients and mouse models with different cancer types (gastrointestinal, colon, and pancreatic cancers). The expression data were obtained in distinct muscles: three studies present data from the gastrocnemius, three from the quadriceps, one from the rectus abdominis, one from the biceps femoris, and one from the extensor digitorum longus. This variability in skeletal muscle phenotype expands the transcript profiles, increasing the number of possibilities for identification of key common molecular pathways in muscle wasting triggered by different cancer types. Most of these studies were performed in a limited number of samples (3-21 samples/group), and therefore, a comprehensive and integrative analysis of these data may reveal new molecular components that are not identified when these studies are analyzed individually.

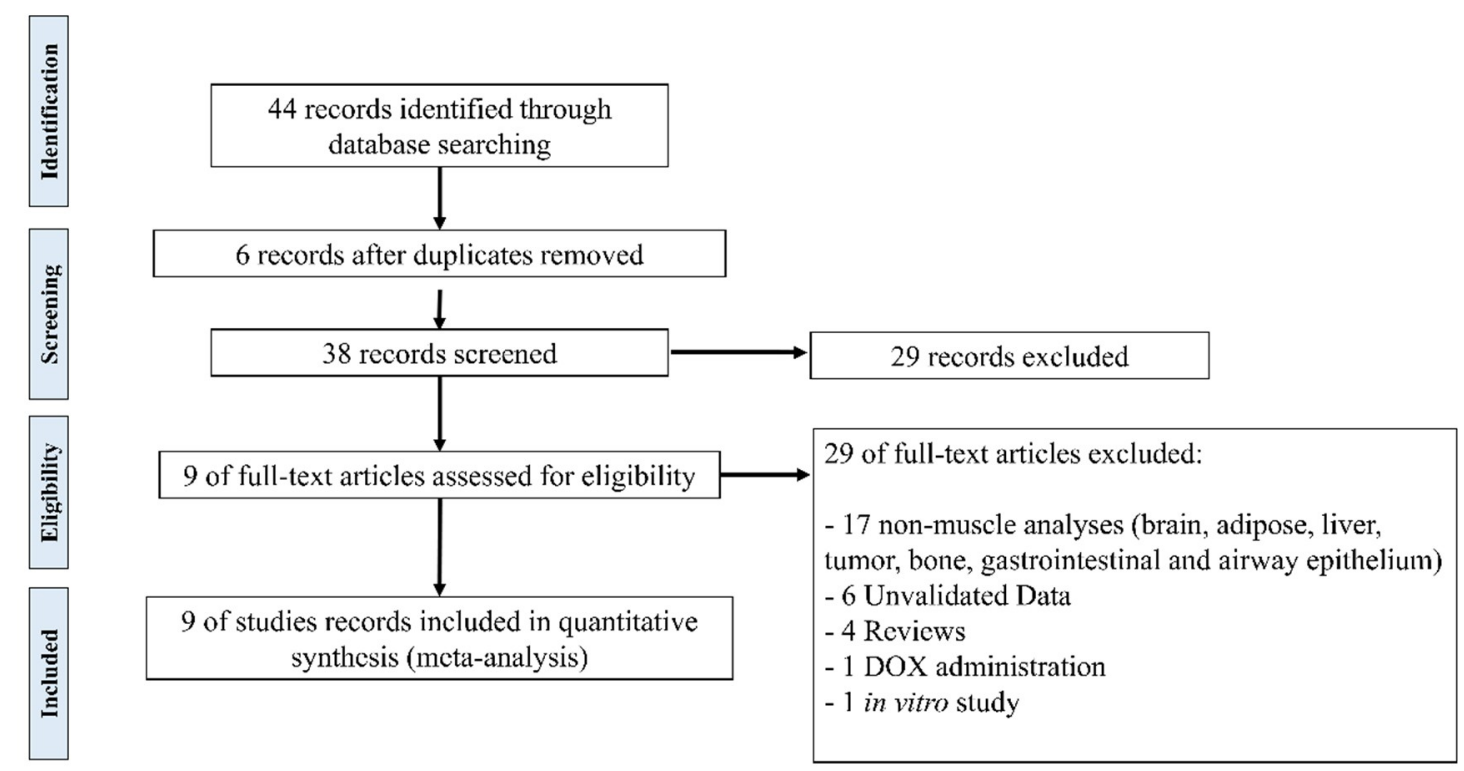

Figure 1. Flow chart of literature search in the meta-analysis. 
Table 1. Description of publicly available studies used in the meta-analysis.

\begin{tabular}{|c|c|c|c|c|c|c|}
\hline Authors & Gene Expression Platforms & Validation Platforms & Muscle & $\begin{array}{c}\text { Cancer Cachexia Study } \\
\text { (Rodent Model or Cancer Type) }\end{array}$ & $\begin{array}{l}\text { Number of Samples } \\
\text { (Cachectic/Control) }\end{array}$ & Ref \\
\hline \multicolumn{7}{|l|}{ Mus Musculus } \\
\hline Tseng et al. 2015 & Illumina HiSeq 2500 & RT & Gastrocnemius & $\begin{array}{l}\text { Colon-26 adenocarcinoma } \\
\text { tumor-bearing mice }\end{array}$ & $3 / 3$ & [36] \\
\hline Roberts et al. 2013 & Illumina Genome Analyzer II & RT, WB & Quadriceps & $\begin{array}{c}\text { Pancreatic } \\
\text { adenocarcinoma-bearing mice }\end{array}$ & $2 / 2$ & [37] \\
\hline Bonetto et al. 2011 & $\begin{array}{l}\text { Illumina MouseWG-6 v2.0 } \\
\text { expression beadchip }\end{array}$ & RT, WB & Quadriceps & $\begin{array}{l}\text { Colon-26 adenocarcinoma } \\
\text { tumor-bearing mice }\end{array}$ & $4 / 4$ & {$[38]$} \\
\hline Gilabert et al. 2014 & $\begin{array}{c}\text { Affymetrix Mouse Gene 1.0 ST } \\
\text { Array }\end{array}$ & RT & Biceps femoris & $\begin{array}{c}\text { Pancreatic } \\
\text { adenocarcinoma-bearing mice }\end{array}$ & $3 / 3$ & [39] \\
\hline Shum et al. 2015 & $\begin{array}{c}\text { Affymetrix Mouse Gene 1.0 ST } \\
\text { Array }\end{array}$ & RT & Gastrocnemius & $\begin{array}{l}\text { Colon- } 26 \text { carcinoma } \\
\text { tumor-bearing mice }\end{array}$ & $3 / 3$ & [40] \\
\hline Fontes-Oliveira et al. 2014 & Affymetrix RAE230Plus & RT & $\begin{array}{l}\text { Extensor Digitorum } \\
\text { Longus }\end{array}$ & $\begin{array}{l}\text { Rats injected with AH-130 } \\
\text { Yoshida ascites hepatoma cells }\end{array}$ & $7 / 6$ & [41] \\
\hline \multicolumn{7}{|l|}{ Homo Sapiens } \\
\hline Martinelli et al. 2016 & $\begin{array}{c}\text { Agilent-014850 Whole Human } \\
\text { Genome Microarray }\end{array}$ & $\mathrm{RT}, \mathrm{WB}$ & Rectus abdominis & $\begin{array}{l}\text { Pancreatic, colorectal, Hepatic, } \\
\text { and renal cancers }\end{array}$ & 115 & {$[43]$} \\
\hline Stephens et al. 2010 & $\begin{array}{l}\text { Affymetrix GeneChip Human } \\
\text { Genome U133 Plus 2.0 Array }\end{array}$ & RT & Rectus abdominis & Gastrointestinal cancer & $18 / 3$ & [28] \\
\hline Gallagher et al. 2012 & $\begin{array}{l}\text { Affymetrix Human Genome } \\
\text { U133 Plus 2.0 Array }\end{array}$ & RT & Quadriceps & Upper gastrointestinal cancer & $12 / 6$ & [29] \\
\hline
\end{tabular}

RT: quantitative reverse transcription polymerase chain reaction (RT-qPCR); WB: western blot; Ref: reference. 


\subsection{Validated Data Selection of Differentially Expressed Genes in Cancer Cachexia}

We filtered the genes with differential expression that were validated by western blotting and/or quantitative reverse transcription polymerase chain reaction (RT-qPCR) techniques. This strategy allowed us to use the transcripts selected as more relevant by the authors in the global analysis, and therefore, specifically investigate those that may be directly related to molecular alterations in muscle wasting in cancer cachexia. These studies reported, excluding duplicates, 52 differentially expressed genes in 59 samples of muscle tissue from patients and rodent models of cancer cachexia. A list of the validated data for differentially expressed genes in cancer cachexia, with their respective functions and location, is summarized in Table 2 and Table S1. We highlight that the atrogenes Fbxo32 and Trim63 appeared in six out of the nine selected studies, and Cebpd and Cxcl12 are dysregulated in two studies. Notably, 10 over-expressed genes (Comp, Mmp3, Adipoq, Angptl7, Fgg, Hp, Mstn, Saa1, Serpina3n, and Cxcl12) are translated into secreted proteins, and therefore, can be further explored as potential cancer cachexia biomarkers.

Table 2. List of 52 differentially expressed genes of skeletal muscle in cancer cachexia samples.

\begin{tabular}{|c|c|c|c|}
\hline Official Symbol & Species & Function & Location \\
\hline \multicolumn{4}{|l|}{ Up-Regulated } \\
\hline TIE1 & $\mathrm{H}$ & Regulation of angiogenesis & Cell Membrane \\
\hline EIF3I & $\mathrm{H}$ & $\begin{array}{l}\text { Cell proliferation, including cell cycling, differentiation } \\
\text { and apoptosis }\end{array}$ & Cytoplasm \\
\hline HGS & $\mathrm{H}$ & $\begin{array}{c}\text { Intracellular signal transduction mediated by } \\
\text { cytokines and growth factors }\end{array}$ & Cytoplasm \\
\hline NUDC & $\mathrm{H}$ & Neurogenesis and neuronal migration & Cytoplasm \\
\hline PCK1 & $\mathrm{H}$ & Metabolic pathway that produces glucose & Cytoplasm \\
\hline TSC2 & $\mathrm{H}$ & $\begin{array}{l}\text { Negatively regulating mTORC1 signaling and playing } \\
\text { a role in microtubule-mediated protein transport }\end{array}$ & Cytoplasm \\
\hline CAMK2B & $\mathrm{H}$ & $\begin{array}{l}\text { Regulation of sarcoplasmic reticulum } \mathrm{Ca} 2+\text { transport } \\
\text { in skeletal muscle }\end{array}$ & $\begin{array}{l}\text { Cytoplasm; Sarcoplasmic } \\
\text { reticulum membrane }\end{array}$ \\
\hline POLRMT & $\mathrm{H}$ & Transcription of mitochondrial DNA into RNA & Mitochondrion \\
\hline COMP & $\mathrm{H}$ & $\begin{array}{l}\text { Suppressor of apoptosis; interact with extracellular } \\
\text { matrix proteins such as the collagens and fibronectin }\end{array}$ & Secreted - ECM \\
\hline MMP3 & $\mathrm{H}$ & $\begin{array}{c}\text { Degrade fibronectin, laminin, gelatins, collagens, and } \\
\text { cartilage proteoglycans }\end{array}$ & Secreted - ECM \\
\hline ADIPOQ & $\mathrm{H}$ & $\begin{array}{l}\text { Control of fat metabolism, insulin sensitivity, cell } \\
\text { growth, angiogenesis and tissue remodeling }\end{array}$ & Secreted - ER \\
\hline ANGPTL7 & $\mathrm{H}$ & $\begin{array}{l}\text { Anti-angiogenic protein and play a role in extracellular } \\
\text { matrix formation }\end{array}$ & Secreted - ER \\
\hline Kcnip4 & M & Modulates channel expression at the cell membrane & Cell Membrane \\
\hline Pnpla2 & M & $\begin{array}{l}\text { Response of the organism to starvation, enhancing } \\
\text { hydrolysis of triglycerides and providing free fatty } \\
\text { acids to other tissues }\end{array}$ & Cell Membrane \\
\hline Socs3 & M & $\begin{array}{c}\text { Negative regulation of cytokines that signal through } \\
\text { the JAK/STAT pathway }\end{array}$ & Cytoplasm \\
\hline Foxo1 & $\mathrm{M}$ & $\begin{array}{l}\text { Autophagic cell death induction in response to } \\
\text { starvation or oxidative stress }\end{array}$ & Cytoplasm and Nucleus \\
\hline Stat3 & M & $\begin{array}{l}\text { Signal transducer and transcription activator that } \\
\text { mediates cellular responses to interleukins and growth } \\
\text { factors }\end{array}$ & Cytoplasm and Nucleus \\
\hline Ufd1 & M & Promote ubiquitination and degradation & Cytoplasm and Nucleus \\
\hline C1s1 & M & Serine protease & $\begin{array}{l}\text { Extracellular exosome; } \\
\text { Extracellular space }\end{array}$ \\
\hline Ucp3 & M & Thermogenesis and energy balance & Mitochondrion \\
\hline Cebpd & M & $\begin{array}{l}\text { Immune and inflammatory responses. Transcriptional } \\
\text { activator that enhances IL6 transcription }\end{array}$ & Nucleus \\
\hline Junb & M & $\begin{array}{l}\text { Regulate gene activity following the primary growth } \\
\text { factor response }\end{array}$ & Nucleus \\
\hline$F g g$ & M & Guide cell migration during re-epithelialization & Secreted \\
\hline
\end{tabular}


Table 2. Cont.

\begin{tabular}{|c|c|c|c|}
\hline Official Symbol & Species & Function & Location \\
\hline HP & M & $\begin{array}{l}\text { Antibacterial activity and plays a role in modulating } \\
\text { many aspects of the acute phase response }\end{array}$ & Secreted \\
\hline Mstn & M & $\begin{array}{c}\text { Acts specifically as a negative regulator of skeletal } \\
\text { muscle growth }\end{array}$ & Secreted \\
\hline Saa1 & $\mathrm{M}$ & Major acute phase protein & Secreted \\
\hline Serpina3n & M & Response to cytokine & Secreted \\
\hline FBXO32 & $\mathrm{H}, \mathrm{M}$ & $\begin{array}{l}\text { Proteasomal degradation of target proteins during } \\
\text { skeletal muscle atrophy }\end{array}$ & Cytoplasm and Nucleus \\
\hline TRIM63 & $\mathrm{H}, \mathrm{M}$ & $\begin{array}{l}\text { Regulates the proteasomal degradation of muscle } \\
\text { proteins and inhibits de novo skeletal muscle protein } \\
\text { synthesis }\end{array}$ & Cytoplasm and Nucleus \\
\hline \multicolumn{4}{|l|}{ Down-Regulated } \\
\hline$A P C D D 1$ & $\mathrm{H}$ & Negative regulator of the Wnt signaling pathway & Cell Membrane \\
\hline$A D C Y 7$ & $\mathrm{H}$ & $\begin{array}{l}\text { Membrane-bound, calcium-inhibitable adenylyl } \\
\text { cyclase }\end{array}$ & Cell Membrane \\
\hline GABARAPL1 & $\mathrm{H}$ & Autophagosome maturation & Cytoplasm \\
\hline HINT3 & $\mathrm{H}$ & $\begin{array}{c}\text { Hydrolyzes phosphoramidate and acyl-adenylate } \\
\text { substrates }\end{array}$ & Cytoplasm and Nucleus \\
\hline NR3C1 & $\mathrm{H}$ & $\begin{array}{l}\text { Affects inflammatory responses, cellular proliferation, } \\
\text { and differentiation in target tissues }\end{array}$ & Cytoplasm and Nucleus \\
\hline RCAN1 & $\mathrm{H}$ & Central nervous system development & Cytoplasm and Nucleus \\
\hline HSP90AB1 & $\mathrm{H}$ & $\begin{array}{l}\text { Maturation, structural maintenance, and proper } \\
\text { regulation of specific target proteins involved, for } \\
\text { instance in cell cycle control and signal transduction }\end{array}$ & $\begin{array}{l}\text { Cytoplasm, nucleus, cell } \\
\text { membrane and secreted }\end{array}$ \\
\hline HSD11B1 & $\mathrm{H}$ & $\begin{array}{l}\text { Reversibly catalyzes the conversion of cortisol to the } \\
\text { inactive metabolite cortisone }\end{array}$ & $\begin{array}{l}\text { Endoplasmic reticulum } \\
\text { membrane }\end{array}$ \\
\hline$B N I P 3$ & $\mathrm{H}$ & $\begin{array}{l}\text { Mitochondrial protein catabolic process; cell death } \\
\text { pathway }\end{array}$ & Mitochondrion \\
\hline SLC25A37 & $\mathrm{H}$ & $\begin{array}{c}\text { Mitochondrial iron transporter that specifically } \\
\text { mediates iron uptake }\end{array}$ & Mitochondrion \\
\hline PAK1 & $\mathrm{H}$ & $\begin{array}{l}\text { Cell adhesion, migration, proliferation, apoptosis, } \\
\text { mitosis, and vesicle-mediated transport processes }\end{array}$ & $\begin{array}{l}\text { Cytoplasm and Cell } \\
\text { Membrane }\end{array}$ \\
\hline PROX1 & $\mathrm{H}$ & $\begin{array}{l}\text { Cell fate determination, gene transcriptional } \\
\text { regulation, and progenitor cell regulation }\end{array}$ & Nucleus \\
\hline Cav1 & M & T-cell proliferation and NF-kappa-B activation & Cell Membrane \\
\hline Fap & M & $\begin{array}{l}\text { Extracellular matrix degradation, tissue remodeling, } \\
\text { fibrosis, wound healing, inflammation and tumor } \\
\text { growth }\end{array}$ & Cell Membrane \\
\hline Actc1 & M & Cell motility & Cytoplasm \\
\hline Myh8 & $\mathrm{M}$ & Muscle contraction & Cytoplasm \\
\hline Tuba1a & M & Constituent of microtubules & Cytoplasm \\
\hline Tuba4a & M & Constituent of microtubules & Cytoplasm \\
\hline $\operatorname{Mef} 2 c$ & M & $\begin{array}{l}\text { Controls cardiac morphogenesis and myogenesis, and } \\
\text { is also involved in vascular development }\end{array}$ & Nucleus \\
\hline$T f_{c p} 2$ & M & $\begin{array}{l}\text { Binds a variety of cellular promoters, including } \\
\text { fibrinogen and alpha-globin promoters }\end{array}$ & Nucleus \\
\hline Lama2 & M & $\begin{array}{l}\text { Attachment, migration, and organization of cells by } \\
\text { interacting with extracellular matrix components }\end{array}$ & Secreted $(\mathrm{ECM})$ \\
\hline Fst & M & $\begin{array}{l}\text { Specific inhibitor of the biosynthesis and secretion of } \\
\text { pituitary follicle stimulating hormone (FSH) }\end{array}$ & Secreted (ER) \\
\hline CXCL12 & $\mathrm{H}, \mathrm{M}$ & $\begin{array}{l}\text { Immune surveillance, inflammation response, tissue } \\
\text { homeostasis, and tumor growth and metastasis }\end{array}$ & Secreted \\
\hline
\end{tabular}

H: human samples; M: mouse samples; ER: endoplasmic reticulum; ECM: extracellular matrix; SR: sarcoplasmic reticulum.

\subsection{Gene Ontology Enrichment Analysis of Differentially Expressed Genes in Muscle Wasting in Cancer Cachexia}

Gene ontology (GO) analysis shows information on the biological role of differentially expressed genes involved in muscle wasting in cancer cachexia. We used gene ontology hierarchically structured categories to identify proteins encoded by the up- and down-expressed genes. This analysis revealed over-represented GO categories of biological processes that included structural and development genes (e.g., negative regulation of muscle hypertrophy, anatomical structure morphogenesis, epithelial cell proliferation, muscle organ development, muscle cell differentiation, and tissue development), metabolic process, acute-phase response, and apoptotic process. Other relevant terms enriched in our 
dataset included response to insulin and response to hormone stimulus. The statistically significant enriched GO terms are shown in Figure 2.

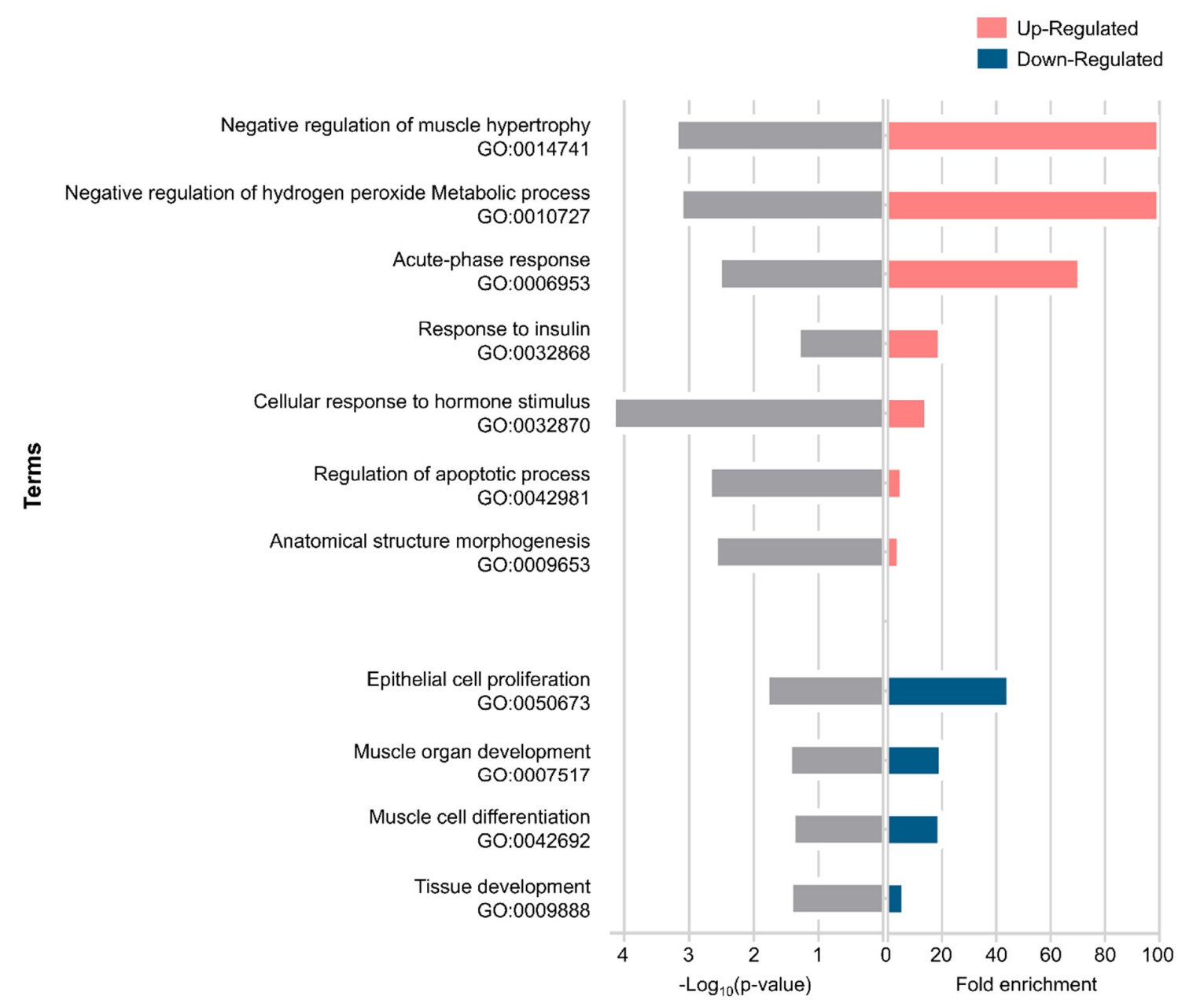

Figure 2. Enrichment pathway analysis of differentially expressed genes in muscle wasting during cancer cachexia. Biological processes identified with up-regulated genes ( $p$-value $\leq 0.00253$ ) and down-regulated genes ( $p$-value $\leq 0.0364)$.

\subsection{Protein-Protein Interaction Network in Muscle Wasting in Cancer Cachexia}

The integrated protein-protein interaction (PPI) network shows a higher number of interactions between proteins of the inflammatory response, catabolism and anabolism, fat metabolism, apoptotic process, and transcriptional control. Complex interactome analysis of deregulated genes in cancer cachexia, with respective functional annotations, is illustrated in Figure 3. 
Inflammatory Response

Transcriptional Factors

Catabolism and Anabolism

Fat Metabolism

Cell adhesion, proliferation and motility

Cell Structure

Apoptotic Process

Extracellular Matrix Modulation

Intracellular Calcium Regulation

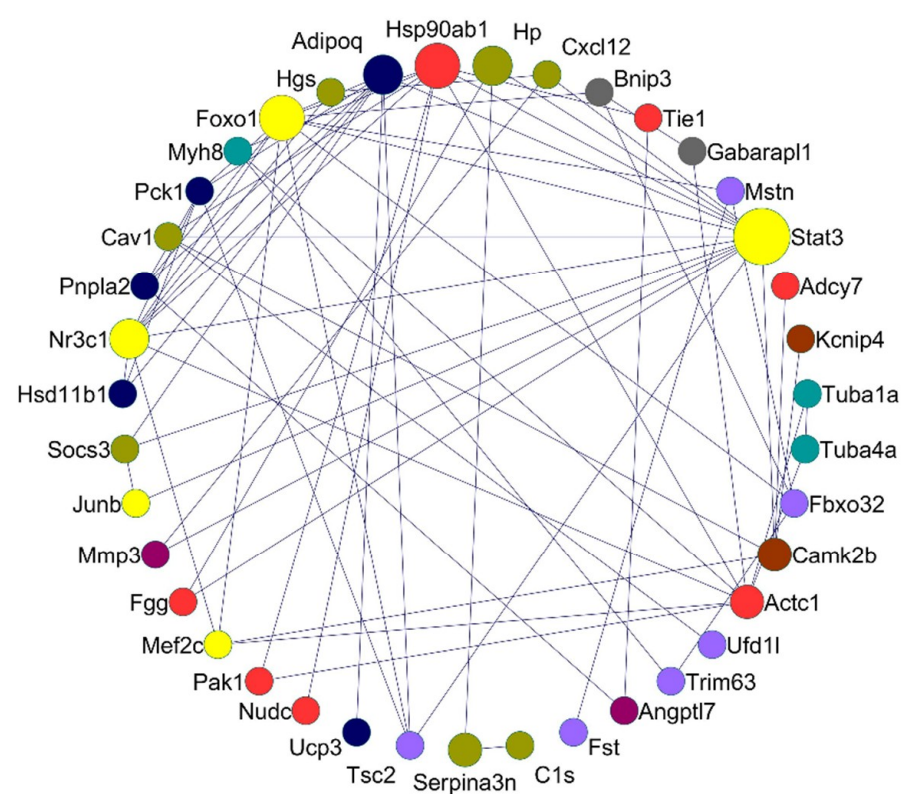

Figure 3. Protein-protein interaction (PPI) network in muscle wasting in cancer cachexia. Lines highlight PPI, with Stat3, Foxo1, Camk2b, Adipoq, Nr3c1, and Actc1 presenting the highest number of interactions. Colors highlight biological processes or molecular function of the circle network components. The larger the circle, the higher the number of interactions identified. STRING v10.5.1 was used to generate protein interactions, and the resulting network was visualized using Cytoscape v3.4.0.

\subsection{Identification of New Potential microRNA-Regulated Networks in Muscle Wasting in Cancer Cachexia}

The miRNA-mRNA target prediction identified 3150 non-validated and 98 validated interactions (Tables S2 and S3). The validated interactions were used to construct a microRNA-target mRNA interaction network for up- and down-regulated genes (Figure 4A,B, respectively). Networks were constructed with our list of microRNAs predicted in silico as targeting the mRNAs retrieved by our meta-analysis, and with microRNAs found as deregulated in two previous microRNAs studies on muscle wasting in cancer cachexia [34,35] (Table S2). Interestingly, the intersection of all the microRNA data showed that our list of predicted microRNAs shares five microRNAs with one study [35] (miR-27a, miR-27b, miR-140, miR-24, and miR-15) and the microRNA miR-199 with another [34] (Figure 5A).

Next, we predicted genes targeted by the differentially expressed microRNAs by both these previous studies. These genes were further compared with the list of 52 deregulated genes identified in our meta-analysis. We found a total of five shared transcripts (Cav1, Cxcl12, Foxo1, Mef2c, and Junb) (Figure 5B), and most importantly, these five transcripts revealed seven new microRNA-mRNA interactions in muscle wasting in cancer cachexia (miR-27a/Foxo1, miR-27a/Mef2c, miR-27b/Cxcl12, miR-27b/Mef2c, miR-140/Cxcl12, miR-199a/Cav1, and miR-199a/Junb) (Table 3). Notably, three interactions-miR-27a/Foxo1, miR-140/Cxcl12, and miR-199a/Cav1—showed an opposite direction of expression between microRNAs (identified in the previous studies [34,35]) and mRNAs (identified in the meta-analysis) (Table 3). 
A

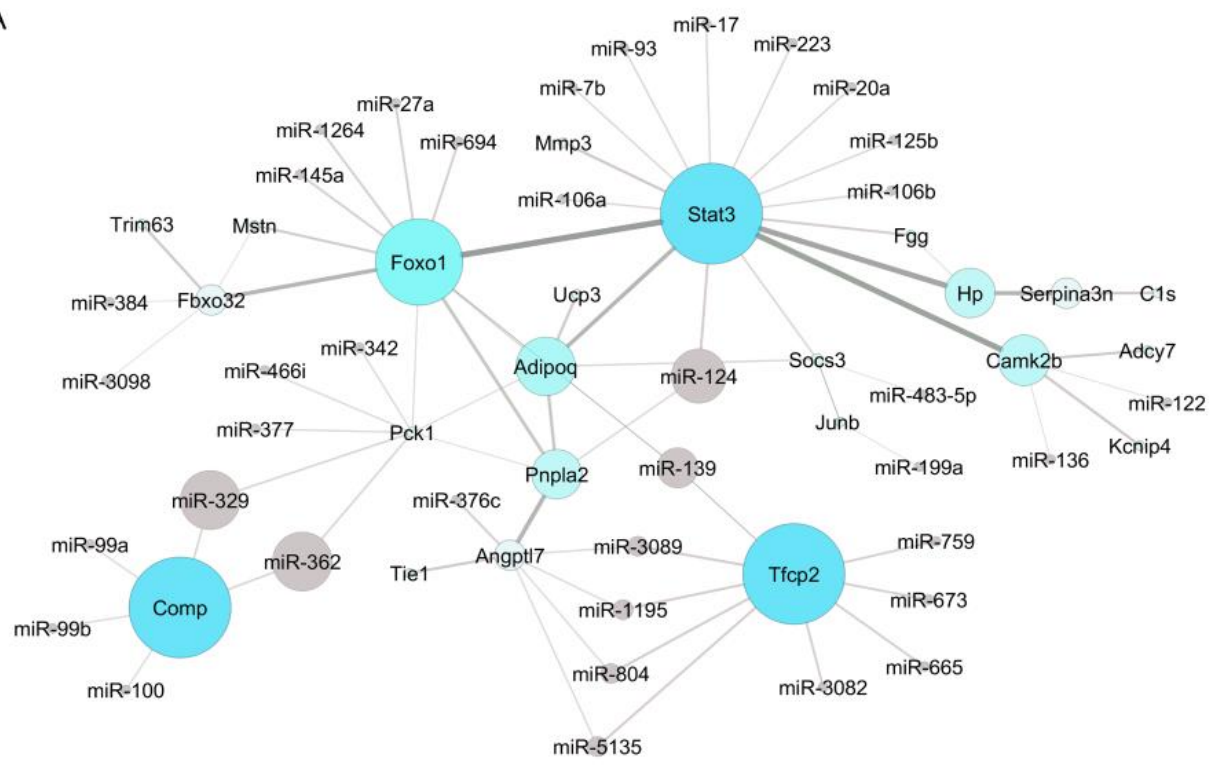

B

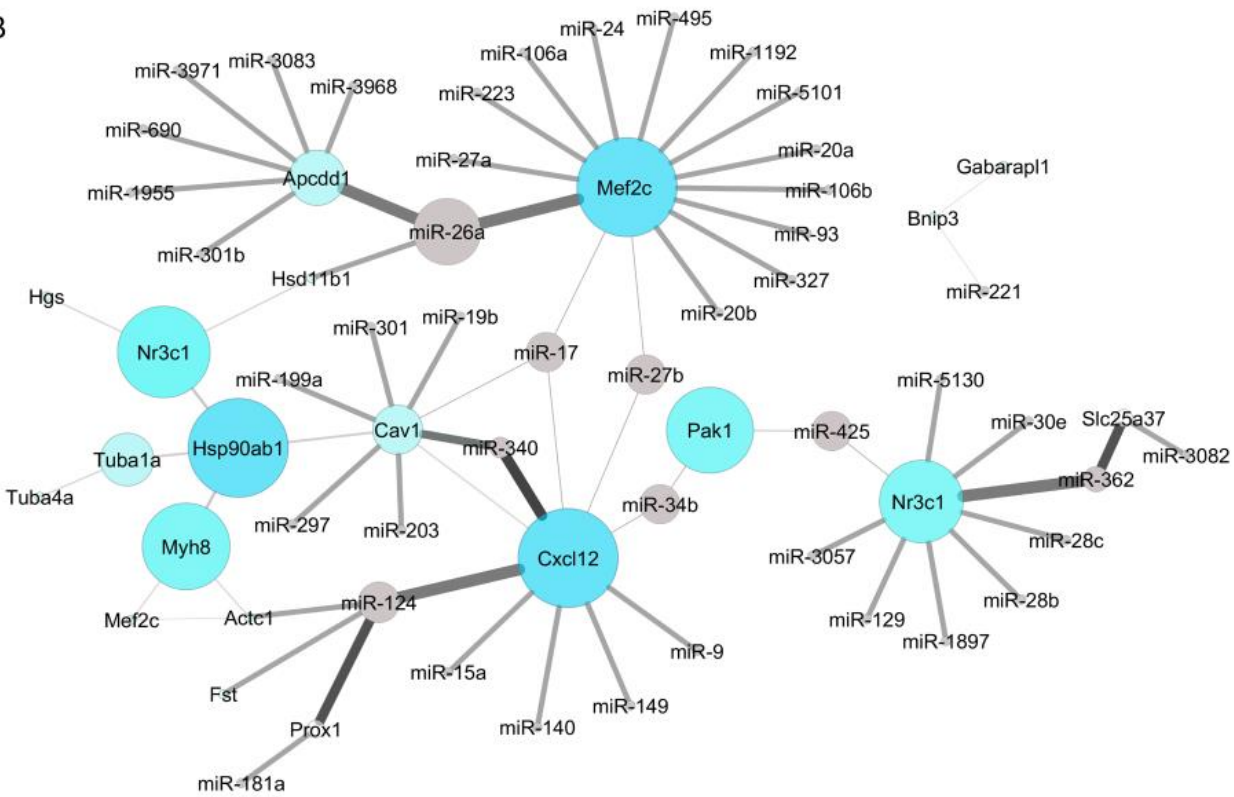

Figure 4. The miRNA-mRNA target interaction network in muscle wasting in cancer cachexia. (A) Interactome between up-regulated genes and the respective potential regulatory microRNAs. The larger the circles, the higher the number of interactions identified. Gray lines highlight the interactions; line thickness reflects the betweenness centrality. (B) Interactome between down-regulated genes and the potential regulatory microRNAs. The larger the circles, the higher the number of interactions identified. Gray lines highlight the interactions; line thickness refers to the betweenness centrality. MicroRNA-gene interactions were visualized using Cytoscape v3.4.0. 
A

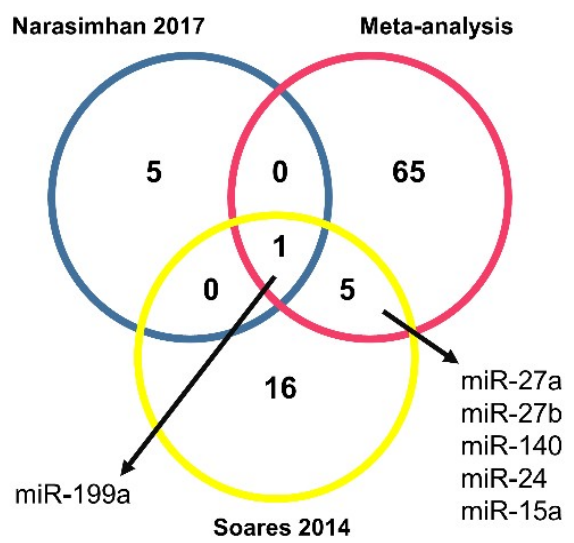

B

B mRNAs

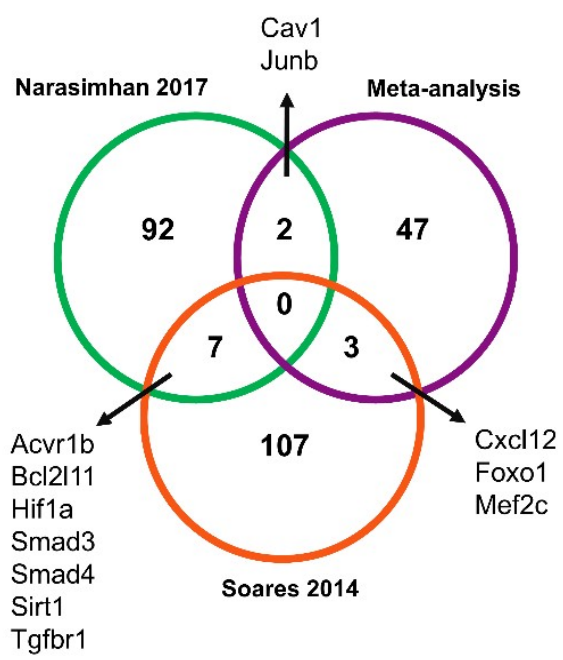

Figure 5. MicroRNAs and mRNAs identified in muscle wasting in cancer cachexia. (A) MicroRNAs predicted in silico as targeting mRNAs retrieved by our meta-analysis (pink circle) were further compared with microRNAs identified as differentially expressed in previous studies of muscle wasting in cancer cachexia, performed by Soares et al. [35] (yellow circle) and Narasimhan et al. [34] (blue circle). (B) Venn Diagram comparing the predicted microRNA target for Soares et al. [35] (red circle) and Narasimhan et al. [34] (green circle) with the list of 52 deregulated genes in muscle wasting in cancer cachexia identified in our meta-analysis (purple circle).

Table 3. Identification of new relevant microRNA-mRNA interaction in muscle wasting in cancer cachexia.

\begin{tabular}{ccc}
\hline \multirow{2}{*}{ Study } & \multicolumn{2}{c}{ microRNA/mRNA Interactions } \\
\cline { 2 - 3 } & microRNA & mRNA * \\
\hline & $\downarrow$ miR-27b & $\downarrow$ Cxcl12 \\
& $\uparrow$ miR-140 & $\downarrow$ Cxcl12 \\
Soares et al. [35] & $\downarrow$ miR-27a & $\uparrow$ Foxo1 \\
& $\downarrow$ miR-27a & $\downarrow$ Mef2c \\
& $\downarrow$ miR-27b & $\downarrow$ Mef2c \\
Narasimhan et al. [34] & $\uparrow$ miR-199a & $\uparrow$ Junb \\
& $\uparrow$ miR-199a & $\downarrow$ Cav1
\end{tabular}

Up arrow: up-regulated genes; down arrow: down-regulated genes; ${ }^{*}$ mRNAs identified in our meta-analysis.

\subsection{Identification of Potential Target Agents for the Treatment of Muscle Wasting in Cancer Cachexia}

Interestingly, Drug-Gene Interaction Database (DGIdb) data revealed ADIPOQ, CAMK2B, COMP, CXCL12, and MSTN as drug-targetable genes, using chemical compounds such as Spironolactone, Fenofibrate, Nevirapine, Mibefradil, Nifedipine, Nisoldipine, Tadalafil, Tinzaparin Sodium, and Stamulumab (Table 4). The above drugs have been demonstrated as clinically useful in Type 2 diabetes mellitus, cardiovascular disease, HIV infection, smooth muscle, cardiac muscle, breast cancer, and myopathies [44-53]. Outstandingly, the potential drugs found here have not been tested yet for the treatment of muscle wasting in cancer cachexia. 
Table 4. Potential target agents identified based on protein-protein interaction networks of deregulated genes in cancer cachexia.

\begin{tabular}{|c|c|c|c|c|c|}
\hline Gene Symbol & Gene Name & Selected Target Agent & Activity & Clinical Relevance & Ref. \\
\hline$A D I P O Q$ & Adiponectin & $\begin{array}{c}\text { Spironolactone, } \\
\text { Fenofibrate, Nevirapine }\end{array}$ & $\begin{array}{l}\text { Aldosterone blocker; } \\
\text { anti-diabetic and } \\
\text { anti-atherosclerotic; } \\
\text { antiretroviral therapy }\end{array}$ & $\begin{array}{l}\text { Type } 2 \text { diabetes mellitus; } \\
\text { cardiovascular disease; } \\
\text { HIV infection }\end{array}$ & [44-46] \\
\hline CAMK2B & $\begin{array}{l}\text { Calcium/calmodulin-dependent } \\
\text { protein kinase II, beta }\end{array}$ & $\begin{array}{l}\text { Mibefradil, Nifedipine, } \\
\text { Nisoldipine }\end{array}$ & Block T-type calcium channel & $\begin{array}{l}\text { Smooth muscle; cardiac } \\
\text { muscle }\end{array}$ & {$[47-49]$} \\
\hline СOMP & $\begin{array}{l}\text { Cartilage oligomeric matrix } \\
\text { protein }\end{array}$ & Tadalafil & Tumor cell growth inhibitory & Breast cancer & [50] \\
\hline MSTN & Myostatin & Stamulumab & $\begin{array}{c}\text { Growth/differentiation factor } 8 \\
\text { inhibitor }\end{array}$ & Myopathies & {$[52,53]$} \\
\hline
\end{tabular}

\section{Discussion}

Researchers have conducted several studies on molecular mechanisms of muscle wasting in cancer cachexia. However, the complexity of the syndrome and the insufficient knowledge of pathogenic mechanisms hinder the design of effective therapeutic strategies. Most cancer cachexia studies rely on a single, thorough, standardized model or specific cancer types, rarely integrating and comparing their datasets with those from other experimental systems. The present meta-analysis allowed us to select relevant mRNA expression data from different cancer cachexia studies. This is the first study integrating the most relevant literature data from global gene expression profiling studies in muscle wasting in cancer cachexia, in order to find common regulatory networks and molecular pathways. We identify new potential microRNA-regulated gene networks involved in muscle wasting in cancer cachexia (Scheme 1). Specifically, our results suggest that microRNA/mRNA interactions miR-27a/Foxo1, miR-27a/Mef2c, miR-27b/Cxcl12, miR-27b/Mef2c, miR-140/Cxcl12, miR-199a/Cav1, and miR-199a/Junb may contribute to muscle wasting in cancer cachexia.

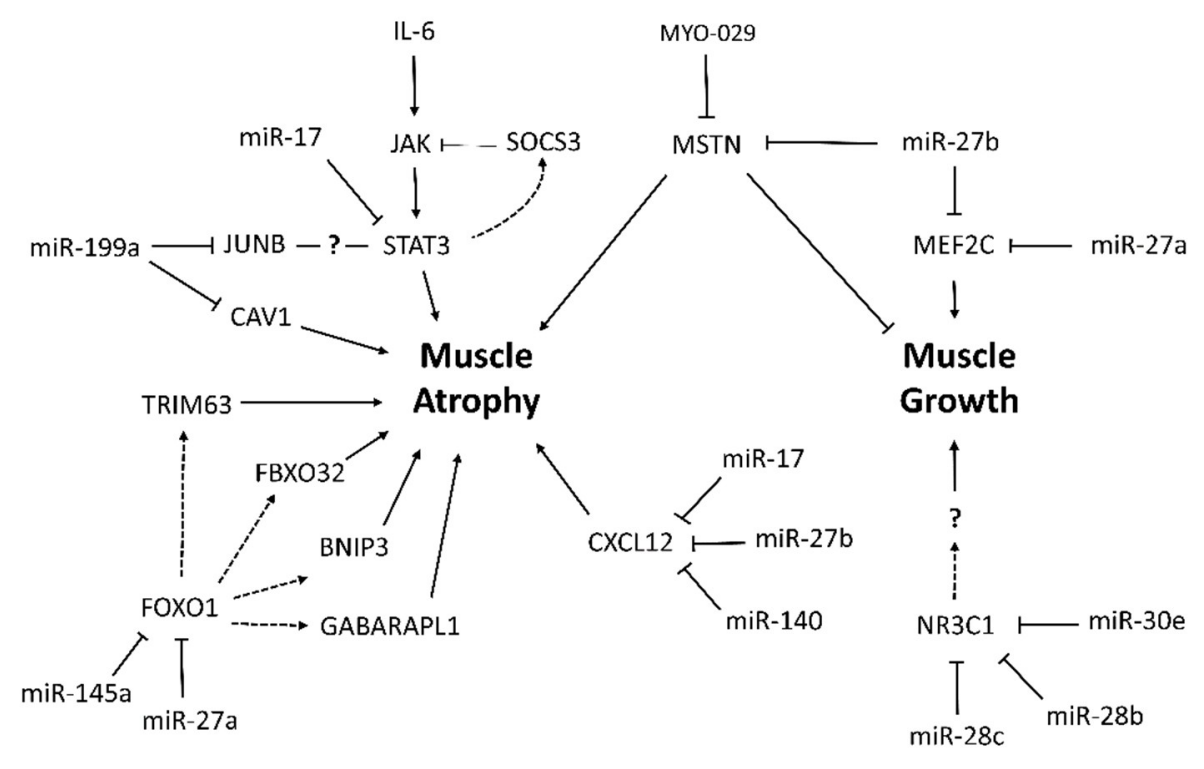

Scheme 1. MicroRNA-regulated networks in muscle wasting during cancer cachexia based on meta-analysis data.

Among the 52 deregulated genes identified in our analysis, six of the nine studies included in the meta-analysis have evaluated the expression of Trim63 and Fbxo32 as molecular markers of muscle atrophy in cancer cachexia. In 2001, Trim63 and Fbxo32 were first identified as two important muscle-specific E3 ubiquitin ligases that are transcriptionally increased in skeletal muscle under atrophy-inducing conditions, making them excellent markers of muscle atrophy [54]. The transcription 
of enzymes Trim63 and Fbxo32 is dependent on transcriptional factors FoxO1 and FoxO3, which are thought to regulate both the ubiquitin/proteasome [27] and autophagy $[20,55,56]$ pathways. Interestingly, our enrichment analysis also showed alteration in the regulation of the apoptotic process induced by changes in the expression of FoxO1, BNIP3, and GABARAPL1. These results are in agreement with the fact that skeletal muscle wasting is the result of an imbalance between synthesis and degradation of protein pathways, together with the instability of regenerative capacity and myocyte apoptosis [57,58].

Moreover, we showed miR-145a as a new potential FoxO1 regulator during muscle wasting in cancer cachexia. Indeed, the increase of miR-145 decreases FoxO1 expression in metastatic T24T bladder cancer cells [59]. Conversely, in non-metastatic bladder transitional cell carcinoma T24 cells, miR-145 overexpression inhibited cell growth, which correlates with upregulation of FoxO1 [59]. These opposite results are probably associated with different cell types and experimental conditions, raising the necessity to further explore miR-145-FoxO1. One of the most important findings of our study was that FoxO1 is a validated target of the microRNA miR-27a. Besides, Soares et al. [35] identified the down-regulation of miR-27a in cancer-cachexia. Although the miR-27a-FoxO1 interaction is not validated in skeletal muscle cells, the overexpression of miR-27a in mice with chronic kidney disease attenuated muscle loss, improved grip strength, and decreased the expression of FoxO1, Trim63, and Fbxo32 proteins [60].

Besides these molecular markers of muscle atrophy, our meta-analysis also identified $\mathrm{Nr} 3 \mathrm{cl}$ as down-regulated in the skeletal muscle of cachectic patients with upper gastrointestinal cancer [29]. $\mathrm{Nr} 3 \mathrm{c} 1$ has a function in the regulation of muscle hypertrophy and strength in response to resistance training [61]; however, the role of $\mathrm{Nr} 3 \mathrm{cl}$ in the development of muscle wasting associated with cancer is still unknown. Furthermore, our microRNA target prediction analysis identified nine microRNAs that potentially modulate $\mathrm{Nr} 3 \mathrm{c} 1$ expression, including microRNAs miR-28b and miR-28c. We also identified that the $N r 3 c 1$ transcript is potentially regulated by miR-30e, which is upregulated in the skeletal muscle of Mstn-/- mice, and its expression was associated with glycolytic myofiber formation [62]. Considering that microRNAs miR-28b, miR-28c, and miR-30e potentially target the Nr3c1 transcript, and that both microRNAs and their target transcripts have important functions previously described in skeletal muscle tissue, our integrative analysis reveals these new microRNA-mRNA interactions as potential targets for future exploratory analysis of muscle wasting in cancer cachexia.

Our prediction analyses also revealed microRNA miR-17 as an important regulator of transcripts, such as Cxcl12, Mef2c, Stat3, and Cav1, that are translated into proteins with a role in cancer cachexia. MicroRNA miR-17 is involved in oncogenic events in different cancer types with a high incidence of cachexia (hepatocellular carcinoma [63], pancreatic cancer [64], and non-small lung cancer [65,66]). Among the miR-17 target genes, Mef $2 c$ is involved in the regulation of skeletal muscle regeneration and myogenesis (reviewed in Dong et al. [67]). Also, two studies have identified miR-27b as a regulator of Mef2c [68,69]; notably, one of these studies shows that miR-27b is involved in the regulation of mitochondrial biogenesis in myocytes by regulating Mef2c [69]. Importantly, miR-27b also negatively regulates myostatin (Mstn) to promote satellite cell activation and myoblast proliferation, and to prevent muscle wasting [70]. Mstn, a member of the TGF $\beta$ superfamily of growth factors, is a highly conserved negative regulator of skeletal muscle mass upregulated in muscle wasting conditions, including cancer cachexia [37,71,72]. Accordingly, Mstn deficiency increase skeletal muscle mass and strength and counterattacks muscle wasting conditions [73]. Several studies have demonstrated the therapeutic potential of Mstn inhibition under muscle wasting conditions as cancer [74,75]; consequently, the identification of Mstn as a putative target of miR-27b has potential therapeutic and biological implications in muscle wasting conditions.

Moreover, our results showed that the drug Stamulumab (MYO-029), known as a potential MSTN inhibitor, was previously tested in clinical studies of subjects with myopathies. This trial showed a potential increase in the muscle size of the subjects, but the researchers observed no improvements in muscle strength or function $[52,53]$. Considering that there are no studies testing MYO-029 on cancer 
cachexia, further studies are needed to demonstrate whether this drug may improve muscle mass and function in this syndrome.

It is also important to highlight that our enrichment analysis identified genes associated with the acute-phase response. Systemic inflammation is a hallmark of cancer cachexia, and this inflammatory response is the main driving force that leads to the metabolic alterations observed in cancer patients [7]. The literature points out several origins of inflammation, including tumor cells and activated immune cells that release cytokines, chemokines, and other inflammatory mediators [76]. Cxcl12 was one of the top transcripts, with the highest number of microRNA interactions identified in our meta-analysis (nine interactions in total). The identification of microRNAs that target CXCL12 is important, because it has been demonstrated that CXCR4 pathway is consistently downregulated in skeletal muscles from mice

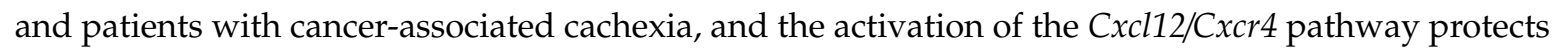
muscle from wasting in mice with the syndrome [43]. This inflammatory chemokine is also relevant in skeletal muscle regeneration by increasing the activity of metalloproteases, which are crucial to the remodeling of the extracellular matrix [77]. Our results also show protein-protein interactions of Cxcl12 with the metalloprotease $\mathrm{Mmp}$, suggesting that this interaction could affect muscle regeneration and extracellular matrix remodeling in cancer cachexia. Indeed, we identified that miR-27b and miR-140 are two potential microRNAs involved in Cxcl12 regulation. Importantly, it has been previously demonstrated that miR-140 transfection decreases Cxcl12 expression and release in human airway smooth muscle cells, with a reduction in inflammatory response [78]. Thus, our data also suggest a response that compromises inflammatory response through the mir-140/Cxcl12 axis in muscle wasting during cancer cachexia.

Furthermore, among the acute phase response genes identified by ontology analysis, Stat3 was the most notorious factor of our interaction network. The role of this transcriptional factor is widely studied in cancer cachexia. The increase of interleukin-6 in cachectic patients triggers the activation of JAK (Janus kinase), with consequent STAT3 phosphorylation that acts at the nucleus; this leads to transcription activation of several genes associated with skeletal muscle cells growth, atrophy, proliferation, differentiation, survival, and apoptosis $[38,79,80]$. Moreover, STAT3 contributes to cancer cachexia enhancing tumorigenesis, metastasis, and immune suppression, mostly in tumors associated with a high prevalence of cachexia [80]. Given the diversity of activated genes obtained through the JAK/STAT pathway, it is essential to better characterize Stat3 downstream target genes in the skeletal muscle cells in wasting conditions. The SOCS3 is a classic inhibitor of the JAK/STAT pathway and several cytokines, and pathogenic mediators induce the expression of SOCS3, which acts in a negative feedback loop to further inhibit signal transduction $[81,82]$. In a murine model of pancreatic cancer cachexia, the JAK/STAT/SOCS3-dependent intracellular pathway plays an essential role in pathogenesis, since its pharmacological inhibition attenuates cachexia progression in a lethal pancreatic cancer model [39].

Our predicted molecular network also revealed a Stat3/Junb interaction. Junb is a transcriptional factor that regulates gene expression on multiple levels [83], but the functionality of this Stat3/Junb interaction deserves future study in relation to cancer cachexia. Our study identified miR-199a as a potential microRNA that modulates Junb expression in muscle wasting in this syndrome. In addition, we found an inverse correlation between miR-199a and Cav1 expression. Since many inflammatory mediators are activated in cancer cachexia, and the miR199a/Cav1 axis was previously described in several chronic inflammatory lung diseases as an important regulatory pathway [84], this axis should also be considered for further investigations in muscle wasting in cancer cachexia.

The main contribution of the present investigation is that we identify new potential microRNA-regulated mRNAs in cancer cachexia. Nevertheless, our study has some limitations due to the nature of our analysis, which consists of the reuse of transcriptomic data from different studies and in silico analysis. Further studies are needed to validate the microRNA-mRNA interactions described herein, as well as to validate the efficiency of the identified potential drugs. Furthermore, the deregulated genes selected in our analysis were restricted to those further validated by RT-qPCR or Western Blot. We considered 
this strategy to increase the possibility of rescuing truly deregulated targets, or with a potential impact on protein levels. Finally, due to the small number of studies evaluating muscle transcriptome of patients with cachexia, we used data from humans and mice together to identify a higher range of transcripts.

In conclusion, we identified new microRNA-mRNA interactions, such as miR-27a/Foxo1, miR-27a/Mef2c, miR-27b/Cxcl12, miR-27b/Mef2c, miR-140/Cxcl12, miR-199a/Cav1, and miR-199a/Junb, that may contribute to muscle wasting in cancer cachexia. Finally, we found drugs targeting MSTN, CXCL12, and CAMK2B, which may be considered for the development of novel therapeutic strategies for cancer-related cachexia.

\section{Methods}

\subsection{Meta-Analysis of Global Gene Expression Data in Muscle Wasting in Cancer Cachexia}

We performed a meta-analysis design following the stages of the PRISMA Statement [85] (Figure 1), by searching PubMed (http://www.ncbi.nlm.nih.gov/pubmed) to find the collection of previously published gene expression data of skeletal muscles in cancer cachexia. The keywords used were: "cancer cachexia AND global gene expression", "cancer cachexia AND transcriptome", "cancer cachexia AND transcriptomics", "cancer cachexia AND microarray", and "cancer cachexia AND RNAseq". These meta-analysis searches comprised studies published between January 2005 and February 2019. Our inclusion criteria were (1) gene expression data in muscle samples of patients with cancer cachexia or animal models of cancer cachexia, (2) all types of cancer were considered, (3) all types of muscle were considered, (4) the inclusion of normal tissues for comparison, (5) all gene expression analysis platforms were considered, and (6) only data further validated by RT-qPCR or Western Blot were included for the integrative analyses. Our exclusion criteria were (1) non-muscle samples, (2) treatment before molecular genetic analysis, and (3) review studies. The deregulated genes reported in selected studies were further used for bioinformatics prediction of microRNAs as potential regulators of gene expression, as described below.

\subsection{Meta-Analysis of Global microRNA Expression Data in Muscle Wasting in Cancer Cachexia}

To search previously published global microRNA expression data for skeletal muscle in cancer cachexia, we used the following keywords in PubMed: "cancer cachexia AND global microRNA expression", "cancer cachexia AND microRNome", and "cancer cachexia AND microRNA profiling". This search only retrieved four studies: (1) microRNA profiling in adipocyte lipolysis [86]; (2) integrative microRNAs and mRNAs expression analysis during skeletal muscle wasting in cardiac cachexia [87]; (3) microRNA profiling in muscle wasting during catabolic conditions, including cancer cachexia [35]; and (4) microRNA profiling from human skeletal muscle in cancer cachexia [34]. The microRNA data of these last two studies were included for the identification of regulatory networks, in addition to the microRNAs that were identified in an in silico, mRNA-based target prediction described subsequently.

\subsection{Identification of Muscle microRNAs as Potential Modulators of Deregulated Genes in Cancer Cachexia}

The deregulated genes identified in our meta-analysis were used for microRNA prediction by multiple algorithms (TargetScan [88], MiRTarBase [89], and miRWalk [90]) to identify potential regulators (predicted and validated interactions) of the expressed genes in cancer cachexia. Next, to generate the interaction networks, we filtered all microRNAs found by these computational tools, considering only those identified by MiRTarBase as presenting the "reporter assay" as a validation method. We selected MiRTarBase [89] due to its different validation methods of interaction between mRNAs and microRNAs, ranging from strong to weak evidence of interaction (accordingly, "reporter assay" has the strongest evidence of microRNA-target gene interaction). We also used MiRTarBase to identify microRNA-target transcripts from global microRNA expression in cancer cachexia studies $[34,35]$. The deregulated genes were used to identify over-represented gene ontology categories 
of biological processes with the Gene Ontology Consortium tool, powered by PANTHER v11.0 [91-93] (available at http://www.pantherdb.org/). We considered the GO categories with $p$-value $\leq 0.05$ to be significant. The UniProtKB database (available at http://www.uniprot.org/) was used to access functional information of components identified through the meta-analysis. Protein-protein interaction (PPI) networks were then generated using Metasearch STRING v10.5.1 [94,95]. Visualization and annotation data of PPI and microRNA-gene interaction networks were generated using Cytoscape v3.4.0 [96].

\subsection{Identification of Candidate Drug Targets Based on microRNA-Regulated Networks in Cancer Cachexia}

We used the Drug-Gene Interaction Database (DGIdb), a database and web interface for finding known and potential drug-gene relationships. Genes were defined by Entrez Gene and Ensembl and were matched with genes from drug-gene interactions and druggable gene categories. The drugs were defined by searching PubChem, and were then matched with drugs from drug-gene interaction data. The source guide to pharmacology interaction was obtained from the DrugBank $[97,98]$.

Supplementary Materials: Supplementary materials can be found at http://www.mdpi.com/1422-0067/20/8/1962/ s1.

Funding: The following grants supported the development of this study: National Council of Technological and Scientific Development (CNPq 141919/2016-7), São Paulo Research Foundation (FAPESP grants \#14/13783-6 and \#12/13961-6), and Coordenação de Aperfeiçoamento Pessoal de Nível Superior-Brasil (CAPES)-grant 88881.187095/2018-01.

Acknowledgments: We wish to acknowledge Vanessa M. Lima and João M. Barguil from the University of São Paulo for helping us with comments that improved our manuscript.

Conflicts of Interest: The authors declare no conflicts of interest.

\section{References}

1. Argilés, J.M.; Busquets, S.; Stemmler, B.; López-Soriano, F.J. Cancer cachexia: Understanding the molecular basis. Nat. Rev. Cancer 2014, 14, 754-762. [CrossRef]

2. Holecek, M. Muscle wasting in animal models of severe illness. Int. J. Exp. Pathol. 2012, 93, 157-171. [CrossRef]

3. Hauser, C.A.; Stockler, M.R.; Tattersall, M.H.N. Prognostic factors in patients with recently diagnosed incurable cancer: A systematic review. Support. Care Cancer 2006, 14, 999-1011. [CrossRef] [PubMed]

4. Laviano, A.; Meguid, M.M.; Inui, A.; Muscaritoli, M.; Rossi-Fanelli, F. Therapy insight: Cancer anorexiacachexia syndrome-when all you can eat is yourself. Nat. Clin. Pract. Oncol. 2005, 2, 158-165. [CrossRef] [PubMed]

5. Fearon, K.C.H. Cancer cachexia: Developing multimodal therapy for a multidimensional problem. Eur. J. Cancer 2008, 44, 1124-1132. [CrossRef] [PubMed]

6. Tisdale, M.J. Cachexia in cancer patients. Nat. Rev. Cancer 2002, 3, 883-889. [CrossRef]

7. Fearon, K.; Strasser, F.; Anker, S.D.; Bosaeus, I.; Bruera, E.; Fainsinger, R.L.; Jatoi, A.; Loprinzi, C.; MacDonald, N.; Mantovani, G.; et al. Definition and classification of cancer cachexia: An international consensus. Lancet Oncol. 2011, 12, 489-495. [CrossRef]

8. Morley, J.E.; Thomas, D.R.; Wilson, M.-M.G. Cachexia: Pathophysiology and clinical relevance. Am. J. Clin. Nutr. 2006, 83, 735-743. [CrossRef]

9. Penafuerte, C.A.; Gagnon, B.; Sirois, J.; Murphy, J.; Macdonald, N.; Tremblay, M.L. Identification of neutrophil-derived proteases and angiotensin II as biomarkers of cancer cachexia. Br. J. Cancer 2016, 114, 680-687. [CrossRef]

10. Kuroda, K.; Nakashima, J.; Kanao, K.; Kikuchi, E.; Miyajima, A.; Horiguchi, Y. Interleukin 6 is associated with cachexia in patients with prostate cancer. Urology 2007, 69, 113-117. [CrossRef]

11. Hou, Y.-C.; Wang, C.-J.; Chao, Y.-J.; Chen, H.-Y.; Wang, H.-C.; Tung, H.-L.; Lin, J.-T.; Shan, Y.-S. Elevated Serum Interleukin-8 Level Correlates with Cancer-Related Cachexia and Sarcopenia: An Indicator for Pancreatic Cancer Outcomes. J. Clin. Med. 2018, 7, 502. [CrossRef] [PubMed] 
12. Kandarian, S.C.; Nosacka, R.L.; Delitto, A.E.; Judge, A.R.; Judge, S.M.; Ganey, J.D.; Moreira, J.D.; Jackman, R.W. Tumour-derived leukaemia inhibitory factor is a major driver of cancer cachexia and morbidity in C26 tumour-bearing mice. J. Cachexia Sarcopenia Muscle 2018, 9, 1109-1120. [CrossRef]

13. Moldawer, L.L.; Georgieff, M.; Lundholm, K. Interleukin 1, tumour necrosis factor-alpha (cachectin) and the pathogenesis of cancer cachexia. Clin. Physiol. 1987, 7, 263-274. [CrossRef]

14. Argilés, J.M.; López-Soriano, F.J. The role of cytokines in cancer cachexia. Med. Res. Rev. 1999, 19, $223-248$. [CrossRef]

15. Ait-Ali, D.; Turquier, V.; Grumolato, L.; Yon, L.; Jourdain, M.; Alexandre, D.; Eiden, L.E.; Vaudry, H.; Anouar, Y. The proinflammatory cytokines tumor necrosis factor-alpha and interleukin-1 stimulate neuropeptide gene transcription and secretion in adrenochromaffin cells via activation of extracellularly regulated kinase 1/2 and p38 protein kinases, and activator pro. Mol. Endocrinol. 2004, 18, 1721-1739. [CrossRef]

16. Yao, X.; Huang, J.; Zhong, H.; Shen, N.; Faggioni, R.; Fung, M.; Yao, Y. Targeting interleukin-6 in inflammatory autoimmune diseases and cancers. Pharmacol. Ther. 2014, 141, 125-139. [CrossRef] [PubMed]

17. Zhang, C.; Li, Y.; Wu, Y.; Wang, L.; Wang, X.; Du, J. Interleukin-6/signal transducer and activator of transcription 3 (STAT3) pathway is essential for macrophage infiltration and myoblast proliferation during muscle regeneration. J. Biol. Chem. 2013, 288, 1489-1499. [CrossRef] [PubMed]

18. Heinrich, P.C.; Behrmann, I.; Haan, S.; Hermanns, H.M.; Müller-Newen, G.; Schaper, F. Principles of interleukin (IL)-6-type cytokine signalling and its regulation. Biochem. J. 2003, 374, 1-20. [CrossRef]

19. Cao, P.R.; Kim, H.J.; Lecker, S.H. Ubiquitin-protein ligases in muscle wasting. Int. J. Biochem. Cell Biol. 2005, 37, 2088-2097. [CrossRef]

20. Zhao, J.; Brault, J.J.; Schild, A.; Cao, P.; Sandri, M.; Schiaffino, S.; Lecker, S.H.; Goldberg, A.L. FoxO3 coordinately activates protein degradation by the autophagic/lysosomal and proteasomal pathways in atrophying muscle cells. Cell Metab. 2007, 6, 472-483. [CrossRef]

21. Samuels, S.E.; Knowles, A.L.; Tilignac, T.; Debiton, E.; Madelmont, J.C.; Attaix, D. Higher skeletal muscle protein synthesis and lower breakdown after chemotherapy in cachectic mice. Am. J. Physiol. Regul. Integr. Comp. Physiol. 2001, 281, R133-R139. [CrossRef] [PubMed]

22. Gomes, M.D.; Lecker, S.H.; Jagoe, R.T.; Navon, A.; Goldberg, A.L. Atrogin-1, a muscle-specific F-box protein highly expressed during muscle atrophy. Proc. Natl. Acad. Sci. USA 2001, 98, 14440-14445. [CrossRef] [PubMed]

23. Stevenson, E.J.; Giresi, P.G.; Koncarevic, A.; Kandarian, S.C. Global analysis of gene expression patterns during disuse atrophy in rat skeletal muscle. J. Physiol. 2003, 551, 33-48. [CrossRef]

24. Giresi, P.G. Identification of a molecular signature of sarcopenia. Physiol. Genom. 2005, 21, 253-263. [CrossRef]

25. Stevenson, E.J.; Koncarevic, A.; Giresi, P.G.; Jackman, R.W.; Kandarian, S.C. Transcriptional profile of a myotube starvation model of atrophy. J. Appl. Physiol. 2005, 98, 1396-1406. [CrossRef]

26. Hasselgren, P.O. Glucocorticoids and muscle catabolism. Curr. Opin. Clin. Nutr. Metab. Care 1999, 2, 201-205. [CrossRef] [PubMed]

27. Sacheck, J.M.; Hyatt, J.-P.K.; Raffaello, A.; Jagoe, R.T.; Roy, R.R.; Edgerton, V.R.; Lecker, S.H.; Goldberg, A.L. Rapid disuse and denervation atrophy involve transcriptional changes similar to those of muscle wasting during systemic diseases. FASEB J. 2007, 21, 140-155. [CrossRef] [PubMed]

28. Stephens, N.A.; Gallagher, I.J.; Rooyackers, O.; Skipworth, R.J.; Tan, B.H.; Marstrand, T.; Ross, J.A.; Guttridge, D.C.; Lundell, L.; Fearon, K.C.; et al. Using transcriptomics to identify and validate novel biomarkers of human skeletal muscle cancer cachexia. Genome Med. 2010, 2, 1. [CrossRef]

29. Gallagher, I.J.; Stephens, N.A.; MacDonald, A.J.; Skipworth, R.J.E.; Husi, H.; Greig, C.A.; Ross, J.A.; Timmons, J.A.; Fearon, K.C.H. Suppression of skeletal muscle turnover in cancer cachexia: Evidence from the transcriptome in sequential human muscle biopsies. Clin. Cancer Res. 2012, 18, 2817-2827. [CrossRef] [PubMed]

30. Güller, I.; Russell, A.P. MicroRNAs in skeletal muscle: Their role and regulation in development, disease and function. J. Physiol. 2010, 588, 4075-4087. [CrossRef]

31. Eisenberg, I.; Alexander, M.S.; Kunkel, L.M. miRNAS in normal and diseased skeletal muscle. J. Cell. Mol. Med. 2009, 13, 2-11. [CrossRef] [PubMed]

32. Eisenberg, I.; Eran, A.; Nishino, I.; Moggio, M.; Lamperti, C.; Amato, A.A.; Lidov, H.G.; Kang, P.B.; North, K.N.; Mitrani-Rosenbaum, $\mathrm{S}$; et al. Distinctive patterns of microRNA expression in primary muscular disorders. Proc. Natl. Acad. Sci. USA 2007, 104, 17016-17021. [CrossRef] 
33. van de Worp, W.R.P.H.; Theys, J.; van Helvoort, A.; Langen, R.C.J. Regulation of muscle atrophy by microRNAs: "AtromiRs" as potential target in cachexia. Curr. Opin. Clin. Nutr. Metab. Care 2018, 21, 423-429. [CrossRef] [PubMed]

34. Narasimhan, A.; Ghosh, S.; Stretch, C.; Greiner, R.; Bathe, O.F.; Baracos, V.; Damaraju, S. Small RNAome profiling from human skeletal muscle: Novel miRNAs and their targets associated with cancer cachexia. J. Cachexia Sarcopenia Muscle 2017, 8, 405-416. [CrossRef]

35. Soares, R.J.; Cagnin, S.; Chemello, F.; Silvestrin, M.; Musaro, A.; De Pitta, C.; Lanfranchi, G.; Sandri, M. Involvement of microRNAs in the regulation of muscle wasting during catabolic conditions. J. Biol. Chem. 2014, 289, 21909-21925. [CrossRef] [PubMed]

36. Tseng, Y.-C.; Kulp, S.K.; Lai, I.-L.; Hsu, E.-C.; He, W.A.; Frankhouser, D.E.; Yan, P.S.; Mo, X.; Bloomston, M.; Lesinski, G.B.; et al. Preclinical Investigation of the Novel Histone Deacetylase Inhibitor AR-42 in the Treatment of Cancer-Induced Cachexia. J. Natl. Cancer Inst. 2015, 107, djv274. [CrossRef]

37. Roberts, E.W.; Deonarine, A.; Jones, J.O.; Denton, A.E.; Feig, C.; Lyons, S.K.; Espeli, M.; Kraman, M.; McKenna, B.; Wells, R.J.B.; et al. Depletion of stromal cells expressing fibroblast activation protein- $\alpha$ from skeletal muscle and bone marrow results in cachexia and anemia. J. Exp. Med. 2013, 210, 1137-1151. [CrossRef]

38. Bonetto, A.; Aydogdu, T.; Kunzevitzky, N.; Guttridge, D.C.; Khuri, S.; Koniaris, L.G.; Zimmers, T.A. STAT3 activation in skeletal muscle links muscle wasting and the acute phase response in cancer cachexia. PLoS ONE 2011, 6, e22538. [CrossRef]

39. Gilabert, M.; Calvo, E.; Airoldi, A.; Hamidi, T.; Moutardier, V.; Turrini, O.; Iovanna, J. Pancreatic cancer-induced cachexia is Jak2-dependent in mice. J. Cell. Physiol. 2014, 229, 1437-1443. [CrossRef] [PubMed]

40. Shum, A.M.Y.; Fung, D.C.Y.; Corley, S.M.; McGill, M.C.; Bentley, N.L.; Tan, T.C.; Wilkins, M.R.; Polly, P. Cardiac and skeletal muscles show molecularly distinct responses to cancer cachexia. Physiol. Genom. 2015, 47, 588-599. [CrossRef] [PubMed]

41. Fontes-Oliveira, C.C.; Busquets, S.; Fuster, G.; Ametller, E.; Figueras, M.; Olivan, M.; Toledo, M.; López-Soriano, F.J.; Qu, X.; Demuth, J.; et al. A differential pattern of gene expression in skeletal muscle of tumor-bearing rats reveals dysregulation of excitation-contraction coupling together with additional muscle alterations. Muscle Nerve 2014, 49, 233-248. [CrossRef]

42. Penna, F.; Busquets, S.; Argilés, J.M. Experimental cancer cachexia: Evolving strategies for getting closer to the human scenario. Semin. Cell Dev. Biol. 2016, 54, 20-27. [CrossRef]

43. Martinelli, G.B.; Olivari, D.; Re Cecconi, A.D.; Talamini, L.; Ottoboni, L.; Lecker, S.H.; Stretch, C.; Baracos, V.E.; Bathe, O.F.; Resovi, A.; et al. Activation of the SDF1/CXCR4 pathway retards muscle atrophy during cancer cachexia. Oncogene 2016, 35, 6212-6222. [CrossRef]

44. Matsumoto, S.; Takebayashi, K.; Aso, Y. The effect of spironolactone on circulating adipocytokines in patients with type 2 diabetes mellitus complicated by diabetic nephropathy. Metabolism 2006, 55, 1645-1652. [CrossRef]

45. Hiuge, A.; Tenenbaum, A.; Maeda, N.; Benderly, M.; Kumada, M.; Fisman, E.Z.; Tanne, D.; Matas, Z.; Hibuse, T.; Fujita, K.; et al. Effects of peroxisome proliferator-activated receptor ligands, bezafibrate and fenofibrate, on adiponectin level. Arterioscler. Thromb. Vasc. Biol. 2007, 27, 635-641. [CrossRef] [PubMed]

46. Petit, J.M.; Duong, M.; Masson, D.; Buisson, M.; Duvillard, L.; Bour, J.B.; Brindisi, M.C.; Galland, F.; Guiguet, M.; Gambert, P.; et al. Serum adiponectin and metabolic parameters in HIV-1-infected patients after substitution of nevirapine for protease inhibitors. Eur. J. Clin. Investig. 2004, 34, 569-575. [CrossRef] [PubMed]

47. Martin, R.L.; Lee, J.H.; Cribbs, L.L.; Perez-Reyes, E.; Hanck, D.A. Mibefradil block of cloned T-type calcium channels. J. Pharmacol. Exp. Ther. 2000, 295, 302-308.

48. Liao, P.; Yu, D.; Li, G.; Yong, T.F.; Soon, J.L.; Chua, Y.L.; Soong, T.W. A smooth muscle Cav1.2 calcium channel splice variant underlies hyperpolarized window current and enhanced state-dependent inhibition by nifedipine. J. Biol. Chem. 2007, 282, 35133-35142. [CrossRef]

49. Splawski, I.; Timothy, K.W.; Sharpe, L.M.; Decher, N.; Kumar, P.; Bloise, R.; Napolitano, C.; Schwartz, P.J.; Joseph, R.M.; Condouris, K.; et al. $\mathrm{Ca}(\mathrm{V}) 1.2$ calcium channel dysfunction causes a multisystem disorder including arrhythmia and autism. Cell 2004, 119, 19-31. [CrossRef] 
50. Mohamed, H.A.; Girgis, N.M.R.; Wilcken, R.; Bauer, M.R.; Tinsley, H.N.; Gary, B.D.; Piazza, G.A.; Boeckler, F.M.; Abadi, A.H. Synthesis and molecular modeling of novel tetrahydro- $\beta$-carboline derivatives with phosphodiesterase 5 inhibitory and anticancer properties. J. Med. Chem. 2011, 54, 495-509. [CrossRef] [PubMed]

51. Koo, C.-Y.; Sen, Y.-P.; Bay, B.-H.; Yip, G.W. Targeting heparan sulfate proteoglycans in breast cancer treatment. Recent Pat. Anticancer Drug Discov. 2008, 3, 151-158. [CrossRef]

52. Bogdanovich, S.; Krag, T.O.B.; Barton, E.R.; Morris, L.D.; Whittemore, L.-A.; Ahima, R.S.; Khurana, T.S. Functional improvement of dystrophic muscle by myostatin blockade. Nature 2002, 420, 418-421. [CrossRef]

53. Wagner, K.R.; Fleckenstein, J.L.; Amato, A.A.; Barohn, R.J.; Bushby, K.; Escolar, D.M.; Flanigan, K.M.; Pestronk, A.; Tawil, R.; Wolfe, G.I.; et al. A phase I/IItrial of MYO-029 in adult subjects with muscular dystrophy. Ann. Neurol. 2008, 63, 561-571. [CrossRef]

54. Bodine, S.C.; Latres, E.; Baumhueter, S.; Lai, V.K.; Nunez, L.; Clarke, B.A.; Poueymirou, W.T.; Panaro, F.J.; $\mathrm{Na}$, E.; Dharmarajan, K.; et al. Identification of ubiquitin ligases required for skeletal muscle atrophy. Science 2001, 294, 1704-1708. [CrossRef]

55. Mammucari, C.; Milan, G.; Romanello, V.; Masiero, E.; Rudolf, R.; Del Piccolo, P.; Burden, S.J.; Di Lisi, R.; Sandri, C.; Zhao, J.; et al. FoxO3 controls autophagy in skeletal muscle in vivo. Cell Metab. 2007, 6, 458-471. [CrossRef] [PubMed]

56. Sin, T.K.; Yu, A.P.; Yung, B.Y.; Yip, S.P.; Chan, L.W.; Wong, C.S.; Ying, M.; Rudd, J.A.; Siu, P.M. Modulating effect of SIRT1 activation induced by resveratrol on Foxo1-associated apoptotic signalling in senescent heart. J. Physiol. 2014, 592, 2535-2548. [CrossRef] [PubMed]

57. Penna, F.; Costamagna, D.; Pin, F.; Camperi, A.; Fanzani, A.; Chiarpotto, E.M.; Cavallini, G.; Bonelli, G.; Baccino, F.M.; Costelli, P. Autophagic degradation contributes to muscle wasting in cancer cachexia. Am. J. Pathol. 2013, 182, 1367-1378. [CrossRef]

58. Argilés, J.M.; Busquets, S.; Stemmler, B.; López-Soriano, F.J. Cachexia and sarcopenia: Mechanisms and potential targets for intervention. Curr. Opin. Pharmacol. 2015, 22, 100-106. [CrossRef]

59. Jiang, G.; Huang, C.; Li, J.; Huang, H.; Jin, H.; Zhu, J.; Wu, X.-R.; Huang, C. Role of STAT3 and FOXO1 in the Divergent Therapeutic Responses of Non-metastatic and Metastatic Bladder Cancer Cells to miR-145. Mol. Cancer Ther. 2017, 16, 924-935. [CrossRef]

60. Wang, B.; Zhang, C.; Zhang, A.; Cai, H.; Price, S.R.; Wang, X.H. MicroRNA-23a and MicroRNA-27a Mimic Exercise by Ameliorating CKD-Induced Muscle Atrophy. J. Am. Soc. Nephrol. 2017, 28, 2631-2640. [CrossRef] [PubMed]

61. Ash, G.I.; Kostek, M.A.; Lee, H.; Angelopoulos, T.J.; Clarkson, P.M.; Gordon, P.M.; Moyna, N.M.; Visich, P.S.; Zoeller, R.F.; Price, T.B.; et al. Glucocorticoid Receptor (NR3C1) Variants Associate with the Muscle Strength and Size Response to Resistance Training. PLoS ONE 2016, 11, e0148112. [CrossRef] [PubMed]

62. Jia, H.; Zhao, Y.; Li, T.; Zhang, Y.; Zhu, D. miR-30e is negatively regulated by myostatin in skeletal muscle and is functionally related to fiber-type composition. Acta Biochim. Biophys. Sin. (Shanghai) 2017, 49, 392-399. [CrossRef]

63. Zhu, H.; Han, C.; Wu, T. MiR-17-92 cluster promotes hepatocarcinogenesis. Carcinogenesis 2015, 36, 1213-1222. [CrossRef] [PubMed]

64. Cioffi, M.; Trabulo, S.M.; Sanchez-Ripoll, Y.; Miranda-Lorenzo, I.; Lonardo, E.; Dorado, J.; Reis Vieira, C.; Ramirez, J.C.; Hidalgo, M.; Aicher, A.; et al. The miR-17-92 cluster counteracts quiescence and chemoresistance in a distinct subpopulation of pancreatic cancer stem cells. Gut 2015, 64, 1936-1948. [CrossRef]

65. Chatterjee, A.; Chattopadhyay, D.; Chakrabarti, G. miR-17-5p downregulation contributes to paclitaxel resistance of lung cancer cells through altering beclin1 expression. PLoS ONE 2014, 9, e95716. [CrossRef]

66. Zhao, J.; Fu, W.; Liao, H.; Dai, L.; Jiang, Z.; Pan, Y.; Huang, H.; Mo, Y.; Li, S.; Yang, G.; et al. The regulatory and predictive functions of miR-17 and miR-92 families on cisplatin resistance of non-small cell lung cancer. BMC Cancer 2015, 15, 731. [CrossRef]

67. Dong, C.; Yang, X.-Z.; Zhang, C.-Y.; Liu, Y.-Y.; Zhou, R.-B.; Cheng, Q.-D.; Yan, E.-K.; Yin, D.-C. Myocyte enhancer factor 2C and its directly-interacting proteins: A review. Prog. Biophys. Mol. Biol. 2017, 126, 22-30. [CrossRef]

68. Chinchilla, A.; Lozano, E.; Daimi, H.; Esteban, F.J.; Crist, C.; Aranega, A.E.; Franco, D. MicroRNA profiling during mouse ventricular maturation: A role for miR-27 modulating Mef2c expression. Cardiovasc. Res. 2011, 89, 98-108. [CrossRef] 
69. Shen, L.; Chen, L.; Zhang, S.; Du, J.; Bai, L.; Zhang, Y.; Jiang, Y.; Li, X.; Wang, J.; Zhu, L. MicroRNA-27b Regulates Mitochondria Biogenesis in Myocytes. PLoS ONE 2016, 11, e0148532. [CrossRef]

70. McFarlane, C.; Vajjala, A.; Arigela, H.; Lokireddy, S.; Ge, X.; Bonala, S.; Manickam, R.; Kambadur, R.; Sharma, M. Negative auto-regulation of myostatin expression is mediated by Smad3 and microRNA-27. PLoS ONE 2014, 9, e87687. [CrossRef]

71. Rodriguez, J.; Vernus, B.; Chelh, I.; Cassar-Malek, I.; Gabillard, J.C.; Hadj Sassi, A.; Seiliez, I.; Picard, B.; Bonnieu, A. Myostatin and the skeletal muscle atrophy and hypertrophy signaling pathways. Cell. Mol. Life Sci. 2014, 71, 4361-4371. [CrossRef]

72. Argilés, J.M.; Orpí, M.; Busquets, S.; López-Soriano, F.J. Myostatin: More than just a regulator of muscle mass. Drug Discov. Today 2012, 17, 702-709. [CrossRef] [PubMed]

73. Han, H.Q.; Mitch, W.E. Targeting the myostatin signaling pathway to treat muscle wasting diseases. Curr. Opin. Support. Palliat. Care 2011, 5, 334-341. [CrossRef]

74. Smith, R.C.; Lin, B.K. Myostatin inhibitors as therapies for muscle wasting associated with cancer and other disorders. Curr. Opin. Support. Palliat. Care 2013, 7, 352-360. [CrossRef]

75. Gallot, Y.S.; Durieux, A.-C.; Castells, J.; Desgeorges, M.M.; Vernus, B.; Plantureux, L.; Rémond, D.; Jahnke, V.E.; Lefai, E.; Dardevet, D.; et al. Myostatin gene inactivation prevents skeletal muscle wasting in cancer. Cancer Res. 2014, 74, 7344-7356. [CrossRef]

76. Argiles, J.M.; Lopez-Soriano, F.J.; Busquets, S. Counteracting inflammation: A promising therapy in cachexia. Crit. Rev. Oncog. 2012, 17, 253-262. [CrossRef]

77. Brzoska, E.; Kowalewska, M.; Markowska-Zagrajek, A.; Kowalski, K.; Archacka, K.; Zimowska, M.; Grabowska, I.; Czerwińska, A.M.; Czarnecka-Góra, M.; Stremińska, W.; et al. Sdf-1 (CXCL12) improves skeletal muscle regeneration via the mobilisation of Cxcr4 and CD34 expressing cells. Biol. Cell 2012, 104, 722-737. [CrossRef] [PubMed]

78. Dileepan, M.; Sarver, A.E.; Rao, S.P.; Panettieri, R.A.; Subramanian, S.; Kannan, M.S. MicroRNA Mediated Chemokine Responses in Human Airway Smooth Muscle Cells. PLoS ONE 2016, 11, e0150842. [CrossRef]

79. Bonetto, A.; Aydogdu, T.; Jin, X.; Zhang, Z.; Zhan, R.; Puzis, L.; Koniaris, L.G.; Zimmers, T.A. JAK/STAT3 pathway inhibition blocks skeletal muscle wasting downstream of IL-6 and in experimental cancer cachexia. Am. J. Physiol. Endocrinol. Metab. 2012, 303, E410-E421. [CrossRef] [PubMed]

80. Zimmers, T.A.; Fishel, M.L.; Bonetto, A. STAT3 in the systemic inflammation of cancer cachexia. Semin. Cell Dev. Biol. 2016, 54, 28-41. [CrossRef]

81. Diao, Y.; Wang, X.; Wu, Z. SOCS1, SOCS3, and PIAS1 promote myogenic differentiation by inhibiting the leukemia inhibitory factor-induced JAK1/STAT1/STAT3 pathway. Mol. Cell. Biol. 2009, 29, 5084-5093. [CrossRef]

82. Lieskovska, J.; Guo, D.; Derman, E. Growth impairment in IL-6-overexpressing transgenic mice is associated with induction of SOCS3 mRNA. Growth Horm. IGF Res. 2003, 13, 26-35. [CrossRef]

83. Mehic, D.; Bakiri, L.; Ghannadan, M.; Wagner, E.F.; Tschachler, E. Fos and jun proteins are specifically expressed during differentiation of human keratinocytes. J. Investig. Dermatol. 2005, 124, 212-220. [CrossRef]

84. Zhang, P.; Cheng, J.; Zou, S.; D’Souza, A.D.; Koff, J.L.; Lu, J.; Lee, P.J.; Krause, D.S.; Egan, M.E.; Bruscia, E.M. Pharmacological modulation of the AKT/microRNA-199a-5p/CAV1 pathway ameliorates cystic fibrosis lung hyper-inflammation. Nat. Commun. 2015, 6, 6221. [CrossRef] [PubMed]

85. Moher, D.; Liberati, A.; Tetzlaff, J.; Altman, D.G. Preferred Reporting Items for Systematic Reviews and Meta-Analyses: The PRISMA Statement. PLoS Med. 2009, 6, e1000097. [CrossRef] [PubMed]

86. Kulyté, A.; Lorente-Cebrián, S.; Gao, H.; Mejhert, N.; Agustsson, T.; Arner, P.; Rydén, M.; Dahlman, I. MicroRNA profiling links miR-378 to enhanced adipocyte lipolysis in human cancer cachexia. Am. J. Physiol. Endocrinol. Metab. 2014, 306, E267-E274. [CrossRef]

87. Moraes, L.N.; Fernandez, G.J.; Vechetti-Júnior, I.J.; Freire, P.P.; Souza, R.W.A.; Villacis, R.A.R.; Rogatto, S.R.; Reis, P.P.; Dal-Pai-Silva, M.; Carvalho, R.F. Integration of miRNA and mRNA expression profiles reveals microRNA-regulated networks during muscle wasting in cardiac cachexia. Sci. Rep. 2017, 7, 6998. [CrossRef] [PubMed]

88. Agarwal, V.; Bell, G.W.; Nam, J.-W.; Bartel, D.P. Predicting effective microRNA target sites in mammalian mRNAs. Elife 2015, 4, e05005. [CrossRef] 
89. Chou, C.-H.; Chang, N.-W.; Shrestha, S.; Hsu, S.-D.; Lin, Y.-L.; Lee, W.-H.; Yang, C.-D.; Hong, H.-C.; Wei, T.-Y.; $\mathrm{Tu}$, S.-J.; et al. miRTarBase 2016: Updates to the experimentally validated miRNA-target interactions database. Nucleic Acids Res. 2016, 44, D239-D247. [CrossRef]

90. Dweep, H.; Sticht, C.; Pandey, P.; Gretz, N. miRWalk-database: Prediction of possible miRNA binding sites by "walking" the genes of three genomes. J. Biomed. Inform. 2011, 44, 839-847. [CrossRef] [PubMed]

91. Mi, H.; Huang, X.; Muruganujan, A.; Tang, H.; Mills, C.; Kang, D.; Thomas, P.D. PANTHER version 11: Expanded annotation data from Gene Ontology and Reactome pathways, and data analysis tool enhancements. Nucleic Acids Res. 2017, 45, D183-D189. [CrossRef] [PubMed]

92. Mi, H.; Dong, Q.; Muruganujan, A.; Gaudet, P.; Lewis, S.; Thomas, P.D. PANTHER version 7: Improved phylogenetic trees, orthologs and collaboration with the Gene Ontology Consortium. Nucleic Acids Res. 2010, 38, D204-D210. [CrossRef] [PubMed]

93. Mi, H.; Lazareva-Ulitsky, B.; Loo, R.; Kejariwal, A.; Vandergriff, J.; Rabkin, S.; Guo, N.; Muruganujan, A.; Doremieux, O.; Campbell, M.J.; et al. The PANTHER database of protein families, subfamilies, functions and pathways. Nucleic Acids Res. 2005, 33, D284-D288. [CrossRef]

94. Szklarczyk, D.; Morris, J.H.; Cook, H.; Kuhn, M.; Wyder, S.; Simonovic, M.; Santos, A.; Doncheva, N.T.; Roth, A.; Bork, P.; et al. The STRING database in 2017: Quality-controlled protein-protein association networks, made broadly accessible. Nucleic Acids Res. 2017, 45, D362-D368. [CrossRef] [PubMed]

95. Snel, B.; Lehmann, G.; Bork, P.; Huynen, M.A. STRING: A web-server to retrieve and display the repeatedly occurring neighbourhood of a gene. Nucleic Acids Res. 2000, 28, 3442-3444. [CrossRef]

96. Shannon, P.; Markiel, A.; Ozier, O.; Baliga, N.S.; Wang, J.T.; Ramage, D.; Amin, N.; Schwikowski, B.; Ideker, T. Cytoscape: A software environment for integrated models of biomolecular interaction networks. Genome Res. 2003, 13, 2498-2504. [CrossRef]

97. Wagner, A.H.; Coffman, A.C.; Ainscough, B.J.; Spies, N.C.; Skidmore, Z.L.; Campbell, K.M.; Krysiak, K.; Pan, D.; McMichael, J.F.; Eldred, J.M.; et al. DGIdb 2.0: Mining clinically relevant drug-gene interactions. Nucleic Acids Res. 2016, 44, D1036-D1044. [CrossRef]

98. Griffith, M.; Griffith, O.L.; Coffman, A.C.; Weible, J.V.; McMichael, J.F.; Spies, N.C.; Koval, J.; Das, I.; Callaway, M.B.; Eldred, J.M.; et al. DGIdb: Mining the druggable genome. Nat. Methods 2013, 10, 1209-1210. [CrossRef] [PubMed]

(C) 2019 by the authors. Licensee MDPI, Basel, Switzerland. This article is an open access article distributed under the terms and conditions of the Creative Commons Attribution (CC BY) license (http://creativecommons.org/licenses/by/4.0/). 